
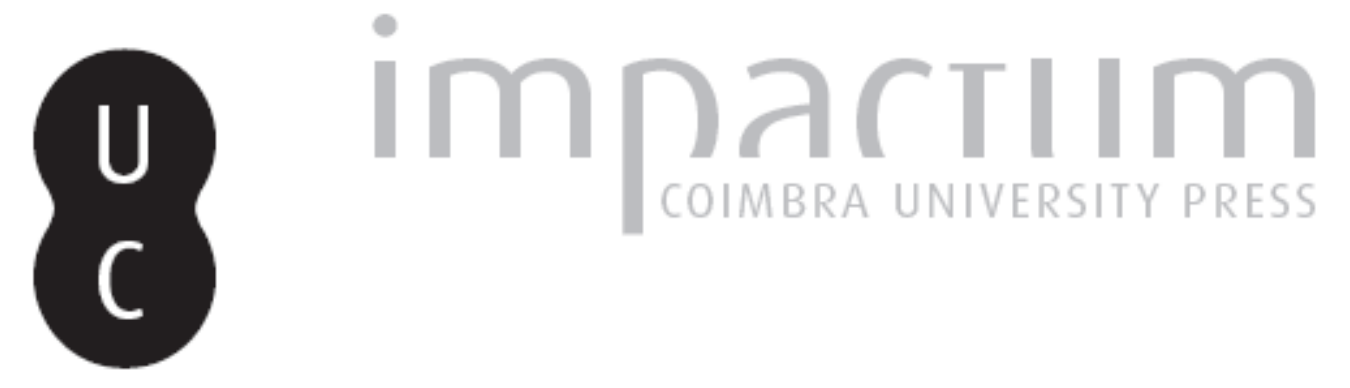

\title{
Measuring firms' financial constraints: a rough guide
}

Autor(es): $\quad$ Silva, Filipe; Carreira, Carlos

Publicado por: Faculdade de Economia da Universidade de Coimbra

URL persistente:

URI:http://hdl.handle.net/10316.2/25201

DOI:

DOI:http://dx.doi.org/10.14195/2183-203X_36_2

Accessed : $\quad$ 26-Apr-2023 14:45:46

A navegação consulta e descarregamento dos títulos inseridos nas Bibliotecas Digitais UC Digitalis, UC Pombalina e UC Impactum, pressupõem a aceitação plena e sem reservas dos Termos e Condições de Uso destas Bibliotecas Digitais, disponíveis em https://digitalis.uc.pt/pt-pt/termos.

Conforme exposto nos referidos Termos e Condições de Uso, o descarregamento de títulos de acesso restrito requer uma licença válida de autorização devendo o utilizador aceder ao(s) documento(s) a partir de um endereço de IP da instituição detentora da supramencionada licença.

Ao utilizador é apenas permitido o descarregamento para uso pessoal, pelo que o emprego do(s) título(s) descarregado(s) para outro fim, designadamente comercial, carece de autorização do respetivo autor ou editor da obra.

Na medida em que todas as obras da UC Digitalis se encontram protegidas pelo Código do Direito de Autor e Direitos Conexos e demais legislação aplicável, toda a cópia, parcial ou total, deste documento, nos casos em que é legalmente admitida, deverá conter ou fazer-se acompanhar por este aviso. 


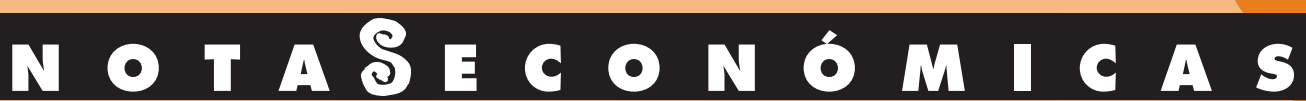

\section{ELSA DE MORAIS SARMENTO / ALCINA NUNES}

\section{FILIPE SILVA / CARLOS CARREIRA}

JOAQUIM ROMERO MAGALHAES

THE DYNAMICS OF EMPLOYER ENTERPRISE CREATION IN PORTUGAL OVER THE LAST TWO DECADES: A FIRM SIZE, REGIONAL AND SECTORAL PERSPECTIVE

\section{MESURING FIRMS' FINANCIAL CONSTRAINTS: A ROUGH GUIDE}

ÚLTIMAS PALAVRAS? 


\section{Measuring Firms' Financial Constraints: A Rough Guide}

\section{Filipe Silva / Carlos Carreira GEMF, University of Coimbra / Faculty of Economics, GEMF, University of Coimbra}

\section{resumo}

Os últimos anos têm sido prolíficos no desenvolvimento de novas medidas de restrições financeiras das empresas. Este artigo analisa as principais estratégias propostas. Discute-se, ainda, as principais vantagens e desvantagens de cada medida, bem como os dados estatísticos necessários para a sua implementação, fornecendo-se assim uma ferramenta útil para os investigadores que pretendem analisar o impacto das restrições financeiras sobre o comportamento das empresas.

\section{abstract}

The recent years have been prolific in terms of development of new measures of firms' financial constraints. This paper surveys the main strategies proposed. Additionally, we discuss the key advantages and disadvantages of each measure as well as the data requirements for implementation. Finally, it provides a useful tool for researchers that intend to analyse the impact of constraints on firm behaviour. 
Firms' access to finance has been an increasingly relevant topic for researchers and policymakers (e.g. OECD, 2012). However, empirically addressing this issue can prove to be a difficult task. In this survey, we summarize the existing approaches and methodologies to measure financial constraints. It is organised in a way that facilitates the comparison of the different methodologies, taking into account the advantages and disadvantages of each approach. This allows the researcher to adequate the most appropriate technique for a research purpose and available data.

Financial constraints are empirically not observable. In fact, there is no item on the balance sheet that tells us if, and the extent to which, a firm is financially constrained. As a result, researchers have strived to develop methodologies that consistently allow identifying and measuring such constraints.

There are, however, a number of specificities associated with financial constraints that one should expect to be reflected in a good measure of financial constraints. Firstly, financial constraints are firm-specific. Even though interest lies in making inferences regarding a certain firm characteristic (e.g. firm size or age) or firm behaviour (e.g. innovation activity), one should expect highly heterogeneous levels of access to external finance. Additionally, constraints are time-varying, since a firm may move from constrained to unconstrained states (or across different degrees of constraint) as, for example, it establishes stronger investor-lender relationships and gains better visibility. The reverse may also be true if, for example, a firm's previously sound economic and financial conditions start to deteriorate (eventually defaulting on previous loans), investment opportunities change or idiosyncratic shocks occur. In this case, it might happen that this previously unconstrained firm will now find it difficult to obtain external finance. Therefore, one might expect different states of constraints along the timeline (e.g. Hubbard, 1998; Cleary, 1999). Finally, financial constraints is not a clear-cut phenomena where a firm is either financially constrained or not, but there are different degrees of constraint (Musso and Schiavo, 2008). As a result, each firm, for a given period of time, may move along a spectrum of constraints. These characteristics imply that, beyond eventual theoretical issues, finding an appropriate measure of financial constraints may prove to be a rather difficult task. Optimally, the perfect measure of financial constraints should be objective, firm-specific, continuous, and time varying. Unfortunately, to our knowledge, there is no such measure. Nevertheless, we will present and discuss the main advantages and disadvantages of existing approaches to measure constraints. A summary of the different methodologies can be found in Appendix Table 1.

\section{Indirect measures}

\subsection{Prologue: Primordial tests and the Q-theory of investment}

Within the traditional Q model for investment (see Chirinko, 1993, for an overview), one should expect that Tobin's $Q$ summarizes all future information that is relevant for a firm when deciding to invest. ${ }^{1}$ Consequently, marginal $Q$ should be the only predictor for investment (Chirinko, 1993). Therefore, we should not expect that additional variables (particularly financial ones) have a significant explanatory power in $\mathrm{Q}$ investment regressions. However, while financial variables, such as cash-flow, have been shown to be relevant in firms' investment decisions, the contribution of $Q$ was found to be disappointingly low (e.g. Blundell et al., 1992). This type of result has driven researchers to argue that (after controlling for $Q$ ) investment may not be

${ }^{1}$ The theory was introduced by Brainard and Tobin (1968) and Tobin (1969). 
independent from financial decisions due to the presence of financial markets imperfections. Specifically, the extent to which financial constraints increase the bias of average $Q$ with respect to marginal $Q$ has been given particular attention (see Hayashi, 1982; Gomes, 2001). If this is the case, then one should expect that financial variables, and specifically those that relate to firms' ability to generate funds, will turn out to be significant in an investment regression - see Hubbard (1998) for further discussion on Q-based models.

\subsection{Cash-Flow Sensitivities}

\subsubsection{Investment}

Theoretically, financial constraints have been incorporated in several models in the past. However, the empirical assessment of financial constraints can essentially be traced back to the seminal work of Fazzari Hubbard and Petersen (1988) - hereafter FHP - that introduced investment to cash-flow sensitivity (ICFS) as a measure of constraints.

The argument is the following. Financially constrained firms cannot obtain external finance - at least the full required amounts, or they do obtain them at significantly high costs. Therefore, these firms must rely on their internally generated funds once an investment opportunity arises. Meanwhile, financially unconstrained firms can easily resort to external funds to finance their investments. Accordingly, while constrained firms will exhibit a positive propensity to use cash-flows to finance investment (positive and significant ICFS), no systematic relationship should be found for unconstrained ones.

The approach used consisted in classifying firms a priori as constrained and unconstrained, based on their dividend policy. By assuming that constrained firms, in order to finance their investment, "retain all of the low-cost internal funds they can generate» and so pay lower dividends, FHP proceed to the estimation of ICFS for each class of firms. They regress investment on cash-flow, estimated $Q$ (investment opportunities) and year and firm dummies, upon a sample consisting of 422 USA firms (1970-84). ${ }^{2}$ Their findings, that low-dividend firms (constrained) exhibit higher ICFS than high-dividend ones (unconstrained), provided evidence that ICFS could be a useful measure of financial constraints.

Since the influential work of FHP, numerous studies focused on the use of ICFS to identify and measure firms' financial constraints - the contributions of Hadlock (1998) for the US, Chapman et al. (1996) for Australia; Guariglia (2008) for the UK; Audretsch, and Elston (2002) for Germany; Kadapakkam et al. (1998) and Bond et al. (2003) for different countries are just examples. Even though this approach is, by far, the most commonly used methodology to assess financial constraints (c.f. Carreira and Silva, 2010), it received severe criticism both at the theoretical and empirical levels. We summarize them into three main critiques that follow.

The first study that definitely challenged FHP's approach was Kaplan and Zingales (1997) - hereafter KZ. They pointed out that, not only certain assumptions made on the curvature of the cost function of external finance may not be verified (e.g. positive third derivatives), but also that the classification scheme used by FHP was flawed. In particular, due to precautionary savings and potentially risky adverse management, the dividend policy is an inaccurate sorting variable.

The second main critique, concerns problems associated with controlling for investment opportunities (FHP use Q). First, it is impossible to measure marginal $Q$ and thus the empirical approximation, average $Q$ (Hayashi, 1982), entails potential mismeasurements due to the violation of certain assumptions, such as imperfect competition and the relationship between

\footnotetext{
${ }^{2}$ As an alternative to the typical $Q$ theory investment regression augmented with cash flow, some researchers also use an accelerator andlor error-correction specifications (e.g. Scellato, 2007; Guariglia, 2008).
} 
firms' investment and financial decisions in these particular types of models (see Chirinko, 1993, and Hubbard, 1998, for a discussion). Second, Cash-Flow might itself contain information about investment opportunities, particularly for firms that face high uncertainty about their investment projects (usually young and growth firms). In this case, cash flow might indicate the direction to go, by revealing additional information on the projects' quality. As a result, one should expect that part of the ICFS is due to investment opportunities that were not captured by $Q$. In fact, Alti (2003), in a financially frictionless model, shows that even after Q correction firms still present significant ICFS.

Finally, several authors such as Povel and Raith (2002), Cleary et al. (2007) or Lyandres (2007) found the ICFS relationship to be non-monotonic. They argue that ICFS are U-shaped with respect to constraints due to the risk associated with firm default and the efforts of investors in trying to avoid corresponding liquidation losses - by providing larger amounts to mitigate the risk of default -, for sufficiently low levels of internal funds. In this case, a decrease in internal funds below a certain threshold would imply an increase in investment

Overall, these critiques cast serious doubts on the robustness of ICFS as a measure of financial constraints.

\subsubsection{Growth}

The approach described in the preceding section, has been extended to firm growth. As a result, a number of researchers have studied financial constraints by estimating the sensitivity of firm growth to cash flow (GCFS). We group these studies into three major categories, depending on the variable used to measure firm growth. Namely, we distinguish between employment growth (e.g. Oliveira and Fortunato, 2006), growth of total assets (e.g. Carpenter and Petersen, 2002) and sales growth (e.g. Fagiolo and Luzzi, 2006).

In this line of thought, we should note that some of these authors conclude that financial constraints (proxied by cash-flow) have a negative impact upon firm growth (e.g. Fagiolo and Luzzi, 2006; Oliveira and Fortunado, 2006). This type of conclusion may, however, be too sudden. Cash-flow per se is just a proxy (a better or worse one) for financial constraints (see Section 5.3). Therefore a positive and significant coefficient for cash-flow only tells us that firm growth responds positively to increases in cash-flow. Accordingly, unless we use a real measure of financial constraints as explanatory variable, or observe different sensitivities for different groups of firms (distinguishing their growth levels), there is not much one can say about the impact of constraints on firm growth. On the other hand, several papers (e.g. Serrasqueiro et al., 2010, Sarno, 2008) fail to control for investment opportunities. In this case, interpreting positive and significant sensitivities for a group of firms as evidence of financial constraints is flawed, due to investment opportunities hidden in cash-flows (see also Alti, 2003).

\subsubsection{Cash}

Recently, in a different perspective of demand for liquidity, Almeida et al. (2004) - hereafter ACW - suggest that financially constrained firms may alternatively be identified by looking at their cash policy. If a firm is constrained, it has to pass-up present investment opportunities and hoard cash, in order to be able to take advantage of profitable future investment opportunities and hedge against future shocks. The same is not true when it comes to unconstrained firms, since they are able to resort to external finance whenever investment opportunities arise (by definition of financial constraints). Therefore, one should expect a positive and significant association between cash stocks and cash-flow for constrained firms, while no such relationship should be found for unconstrained ones. Finally, the degree to which a certain group of firms is financially constrained should be reflected on the cash to cash-flow sensitivity estimate (CCFS), as in ICFS - the higher the CCFS, the more constrained is such group of firms. ACW test if financially constrained firms exhibit high cash-flow sensitivities, while unconstrained firms do not. Results 
for four out of five classification schemes for constrainedlunconstrained firms confirm their hypothesis. Only for the classification based on Kaplan and Zingales (1997), do the results differ. $^{3}$ Examples of this approach can also be found in Han and Qiu (2007) or Baum et al. (2011).

The financial nature of the cash stock variable is a shield against mismeasurements in $Q$ and investment opportunities hidden in cash-flow. The reason being that it is not expected that firms will increase their cash stocks if cash-flow signals a newlbetter investment opportunity, unless they are financially constrained. However, constrained firms may use cash to reduce debt if hedging needs are low (Acharya et al, 2007). Accordingly, one should nevertheless control for debt issuances and investment opportunities. Additionally, as pointed by Almeida et al. (2011) in a subsequent paper, investment in relatively liquid assets, other than cash, may be used to transfer resources across time. ${ }^{4}$ Therefore, any liquid types of investment should also be taken into consideration.

Finally, a few papers have empirically questioned the validity of this measure. They find that all firms, regardless of the a-priori classification as (un)constrained, exhibit positive and significant CCFS (e.g. Pal and Ferrando, 2009). Nevertheless, the sensitivity is found to be higher for firms that are expected to be constrained (Lin, 2007).

\subsubsection{Common pitfalls}

The above mentioned approaches share a number of drawbacks, mostly associated with the ex ante classification of firms, that are worthwhile mentioning. Sample partition into different groups of firms according to a certain segmenting variable that, ex-ante, is expected to provide information on the degree to which firms are financially constrained is, in fact, quite problematic.

First, it is questionable that the segmenting variable correctly distinguishes between constrained and unconstrained firms, since a superior proxy is yet to be found (Musso and Schiavo, 2008). Accordingly, some classification schemes may be flawed. The leading example is provided by Kaplan and Zingales's (2000) critique of FHP's use of dividend policy as a segmenting variable. They find that according to FHP (1988; 2000) Microsoft would be classified as financially constrained, even if it «had net income of $\$ 3.5$ billion, capital expenditures of $\$ 0.5$ billion, no investment in inventories, no dividends, and no debt, yet held almost $\$ 9$ billion of cash - or eighteen times capital expenditures». 5

Second, it is also unclear that this proxy for constraints is not itself affected by financial constraints. In this situation, one will end up with an a-priori classification scheme based on an endogenous variable with respect to constraints - see for example Bond et al. (2003) for ICFS endogeneity problems and estimation biases.

Third, to categorize firms into different groups using continuous segmenting variables, one has to define cut-off points that are not arbitrary. The reason is that the relationship between the segmenting variable and financial constraints may be non-monotonic. As an example, even if it is generally agreed that larger and older firms are not as financially constrained as smaller and younger ones, some studies have shown that this relationship may in fact be U-shaped (e.g. Hadlock and Pierce, 2010).

Fourth, a firm may move across different states of the segmenting variable. Consequently, it might happen that a firm is also moving across different groups. As an example, if one uses firm

\footnotetext{
${ }^{3}$ The classification schemes are based on payout ratio, asset size, bond rating, commercial paper rating, and $\mathrm{KZ}$ index.

${ }^{4}$ In the original model they assumed that firms transfer resources only through cash.

${ }^{5}$ Firms in FHP (1988) and FHP (2000) were a-priori classified as financially constrained if they did not pay dividends and had high cash balances, respectively.
} 
size as proxy, it might happen that a small, but fast growing firm, classified as constrained in the present, will be classified as unconstrained in the future just because it grew. This entails significant problems in the assignment of firms into such classes within a dynamic perspective.

Nevertheless, within cash-flow sensitivities (CFS), an alternative to perform a sample partition with respect to a given variable, is to test interaction terms of that variable with cash-flow. These interaction terms will then provide the sign (but not the magnitude) of the relationship between the variable and financial constraints. This slightly different approach also allows to test for non-monotonic relationships by introducing interactions of cash-flow with power values (e.g. the square) of the selected variable. Additionally, it also permits the treatment of such variable as endogenous in the regression. However, one still has to assume that CFS correctly identifies and measures financial constraints.

\subsection{Euler Equation test}

Based on Q-Theory and within the models for investment with adjustment costs, a strand of literature as attempted to identify financially constrained firms by estimating a reduced form Euler equation (see Whited, 1992).

The underlying Euler equation model describes an optimal path for investment given certain parametric adjustment costs. Accordingly, the marginal costs of investment in the present are set equal to the future's marginal costs of foregone investment. This approach prescribes that under perfect capital markets - i.e. under Modigliani-Miller theorem (1958) - a number of parameter restrictions must be verified (Table 1). Failure to verify such restrictions is interpreted as evidence of financial constraints. Note that these parameters are themselves functions of the model's structural parameters.

This test is then applied to a given subsample of firms. As with cash-flow sensitivity (CFS), researchers classify firms ex-ante as financially constrained based on a given variable (proxy) that is believed to clearly distinguish financially constrained from unconstrained firms.

Accordingly, after deriving an empirical equation from the underlying Euler equation model, one should be able to reject the parameter restrictions for groups of firms that are financially constrained. Conversely, for groups of unconstrained firms, the parameter constraints should be met. ${ }^{6}$ Applications of this methodology can be found, inter alia, in Bond and Meghir (1994) or Love (2003).

The main advantage of this approach over the traditional ICFS is that it avoids measuring $Q$, that may prove to be substantially difficult and confines the analysis to quoted firms. Additionally, the type of data required to the empirical test can be found in many datasets, as it is mostly based on information available in firms' balance sheets. However, the test is derived upon a large number of assumptions and on highly parametric models (see Coad, 2010 for a critique). Furthermore, the framework is based on parameter tests and does not directly produce a variable that can be used in subsequent estimations (see Section 3.2 for an index based on this approach). Finally, as in CFS approaches, a-priory classification schemes may be flawed due to non-monotonic relationships, endogeneity and aggregation issues regarding the proxy used.

\subsection{Evolutionary test of selection forces}

Recent trends, within Evolutionary theory, question the extent to which GCFS are indicative of the presence of financial constraints, rather than just a reflection of the selection process 
mechanism. They challenge the core assumptions of rational optimization and optimal size, present in models of Neoclassical inspiration - such as $Q$ theory and Euler equation approaches. The rationale is that a firm's growth will depend positively on its «fitness", which is reflected on their financial performance relative to others - explaining the positive GCFS found in the literature (see Carreira and Silva, 2010). Therefore, it is natural to expect that the «fittest» firms will grow faster (Coad, 2007).

Firms have «bounded rationality» (Simon, 1991), in the sense that they make decisions based on the information they presently have, rather than based on future states. Within this perspective, only highly productive firms are able to identify highly profitable investment opportunities due to an higher stock of knowledge, better routines and a set of capabilities (Coad, 2010) that lead to a persistence of profit levels (Geroski and Jacquemin, 1988; Dosi, 2007). As a result, it is reasonable to expect a high correlation between profitability and investment opportunities - this rationale is in line with the argument that cash-flows contain information on investment opportunities (Alti, 2003).

Another implication of bounded rationality is that it no longer makes sense thinking in terms of «optimal size» or «optimal path of growth». In fact, Coad (2010) argues that firms always want to grow, and so «evolutionary firms are eternally financially constrained, irrespective of information asymmetries". Accordingly, the extent to which one finds a positive impact of a profitability measure (e.g. operating margin) on firm growth (e.g. sales), is only indicative of the workings of the selection mechanism. In other words, there is a correct reallocation of market share to the most productive firms. ${ }^{7}$ If, on the contrary, growth does not strongly respond to profitability (operating margin), then the selection mechanism is not selecting «the fittest» firms (Coad, 2007; Bottazzi et al., 2008).

However, we should note that the major force behind evolutionary dynamics is firms' ability to innovate (Schumpeter, 1939; Nelson and Winter, 1982; Nelson, 1995), of which one should stress radical innovation - where financial constraints are shown to be particularly severe (Czarnitzki and Hottenrott, 2011). In this perspective, selection forces «unfit» firms to exit, therefore having a "cleansing effect». As a result, if there are external factors that inhibit firms' innovation capacity, the selection process may drive out of the market firms that, even though having the right capabilities, did not have sufficient funds to overtake promising innovation projects. The extent to which financial constraints to innovation ultimately lead to the survival of inert big and established firms in detriment of vibrant new and small innovative firms (thus distorting the selection process), is certainly a question that deserves our attention in the future. ${ }^{8}$

\subsection{Considerations on the data required}

The type of data required to apply the methodologies described in this section is, essentially, information from firms' balance sheets. Despite the pitfalls of these approaches, it is certainly valuable that most National Statistical Offices are able to provide such information for very large (and representative) samples of firms operating in a certain region or country. ${ }^{9}$

However, for some of these approaches, one might also need information from financial markets (in order to compute average $Q$, for example). In the event that such information is strictly necessary, the corresponding sample will only contain publicly traded firms. This has serious

\footnotetext{
7 Usually sales growth is preferred with respect to investment because it captures firms' intangible capital, knowledge, and processes.

${ }^{8}$ Note that several empirical studies find a negative impact of financial constraints on firm survival as well as on innovation (see Carreira and Silva, 2010).

${ }^{9}$ Even for cross-country comparisons, it is possible, although not easy, to obtain such data from International

Organizations (e.g. OECD; World Bank), or to buy this information from specialized data collecting companies.
} 
implications on the measurement of financial constraints. In fact, these firms are expected to be less financially constrained than untraded ones (see Carreira and Silva, 2010). First, traded firms can easily issue equity and debt. Second they have more visibility and are eventually more credible at the eyes of other types of investors Venders. Third, information on these firms is widely available and circulates in a more efficient way (Fama, 1970). This reduces information asymmetries, therefore having a crucial impact upon firms' ability to obtain external funding. This distinction between traded and non-traded firms is particularly relevant for countries with less developed capital markets such as Portugal.

Overall, we should reinforce that indirect measures have two main problems. The first results from the fact that these measures rely on (sometimes strong) theoretical assumptions needed to construct the underlying models for empirical equations. The second is a practical problem associated with the type of measure that is obtained from the estimations. In fact, none of the measures produces a variable that is firm-specific and time-varying. Conversely they only provide a test, based on regression coefficients (or parameters), for the presence of financial constraints within a grouplsubsample of firms.

\section{Direct measures}

As an alternative to measuring financial constraints in an indirect way, when available, a direct measure of financial constraints can prove to be a useful tool that avoids the theoretical and measurement issues described in the preceding section. However, there are specificities associated with this type of measures that one must bear in mind. In this section we refer to two possible ways of directly measuring financial constraints and discuss the implications of using them.

\subsection{Company reports}

Major firms usually provide a report along with their end-of year financial statement - at least those firms that are traded in stock markets are required to do so in most countries. These reports contain rich qualitative information regarding firms' financial position and need for external finance. This information allows researchers to assign each firm a level of financial constraints (e.g. Kaplan and Zingales, 1997; Hadlock and Pierce, 2010).

Here follows an example given by Kaplan and Zingales (1997) of a report of a firm classified as «not financially constrained»: «We ended the year in an exceptionally strong financial condition for a company of our size. During the year we paid off all long-term debt, and our cash and cash-equivalent assets have throughout the year exceeded all current liabilities."

In practice, researchers gather a sample of firms with available company reports. The first step is to search these statements for keywords and expressions that are symptomatic of the presence of financial constraints (Table 1). Secondly, each firm is assigned a level of financial constraints according to the information reported. Finally, if possible, this qualitative information should be complemented with quantitative information (e.g. financial variables) in order to build a final score of financial constraints - in line with Kaplan and Zingales (1997).

While the major advantage of using this type of approach is the richness of information available for the researcher to sort firms according to their levels of constraints, the major drawback is related to the sample size and representativeness of corresponding samples. If on the one hand company reports provide rich and relatively accurate information, on the other hand it is difficult to obtain such information for a large number of firms. Reports are only made available by a small number of firms. Therefore, inferences to the population regarding financial constraints can not be made due to representativeness problems. Among other reasons, these particular firms are usually publicly traded. Accordingly, such firms will, in principle, not be as financially constrained as the untraded ones (see Carreira and Silva, 2010). 
Additionally, analysing company reports entails a significant amount of time and effort. In fact, even if reports were available for the whole population of firms, it would be extremely difficult (or virtually impossible) for the researcher to examine all of them with the necessary level of detail.

Finally, problems associated with managers misreporting may also be relevant in countries where managers may not be held liable for disclosure of false information, or whenever it is not possible to match the information from reports with quantitative data.

\subsection{Self-evaluation: Survey data}

The recent advances in data collection and availability have spawned a new wave of empirical literature that relies on business surveys to identify and measure firms' financial constraints e.g. Savignac (2009); Beck et al. (2008).

The alternative to using firm reports as direct information on firms' ability to obtain external funds, is simply to ask firms whether or not they are financially constrained. This can be done either by a single question, directly asking firms about financial constraints (or access to external finance), or through a combination of a number of different questions. Such questions should regard, among others, the cost of external funds (excessive interest rates), credit denials and the availability of external financing sources. The latter approach requires the construction of a score based on the variables obtained from the different questions, following a given criteria. ${ }^{10}$

The main advantage of using this type of data is the fact that firms are the best informed agents with respect to the quality of their investment projects. Therefore one should expect that investment opportunities are already taken into account in firms' responses. ${ }^{11}$ In addition to directly knowing firms' perception of constraints, unlike reports, one can measure constraints for small and young firms, provided that they are included in the survey's target population.

However, the subjective nature of the self-assessed variables means that potential biases, resulting from individuals' perception, may exist. As an example, we might have respondents that feel that their firm is highly financially constrained, when it actually is much less constrained than another firm reporting a low level of constraints. ${ }^{12}$

Furthermore, it is worthwhile noticing that, due to the non-linear nature of the resulting financial constraints variable, this measure can only be used as a dependent variable, with the appropriate non-linear regression technique. Nevertheless, the non-linear nature of an independent variable can be partially overcome if one previously estimates the corresponding non-linear regression and obtains fitted values of the underlying latent variable - provided that suitable instruments are available and the regression has a good fit. However, in this case we would be working with an index (Section 3.1).

With respect to data availability, although in the past this type of information was rather scarce and with an insufficient level of detail (Claessens and Tzioumis, 2006), we should note that the recent financial crisis has encouraged surveys directly aimed at firms' financial constraints. Examples for the European case are the EUROSTAT's «Access to Finance» and the ECB's "Survey on the Access to Finance of SMEs in the Euro Area». We therefore expect availability of this type of data to be more frequent and detailed in the near future.

\footnotetext{
10 As a mere example, if we have 3 different questions, each one with 3 distinct degrees of response (3 different ordinal variables with 3 levels), a plausible criteria is to build a score of constraints with 3 levels. Firms that answered the maximum (minimum) degrees in all questions are assigned the level 3(1). The remaining firms, that have mixed responses, are assigned the level 2.

11 Note that deliberate missreporting should not be an issue since these types of surveys are usually anonymous.

12 Some studies overcome this problem by using data on the credit requested and effectively granted (e.g. Russo and Rossi, 2001; Angelini and Generale, 2005).
} 
A somewhat different approach (when analysing the bank lending channel) is to ask financial institutions (notoriously banks), rather than firms, the extent to which firm credit was denied and for which reasons - see for example Del Giovane et al., 2010. In this approach, one has the advantage of knowing the reasons for credit denial (controls for lenders perception of risk and project quality). However, there are a number of reasons for which this measure is seldom used. First, it is rather difficult to obtain such data from banks or even specialized institutions (a rare example is the ECB's "Bank Lending Survey for the Euro Area»)..$^{13}$ Second, if one wants to analyse the relationship of financial constraints with other aspects of firm behaviour, one has to match bank with firm level information. This is virtually impossible due to data disclosure policies and confidentiality issues. Third, but related to the previous points, even if it is possible to obtain bank-firm level data, the extent to which the sample will be representative of the population is rather questionable. ${ }^{14}$

These direct measures of constraints all share the advantage of being firm-specific and eventually time-varying - if the reportslsurveys are collected periodically. Additionally, in contrast with indirect approaches, it is possible to use this type of measure either as a dependent or explanatory variable. However, the subjective and qualitative nature of these measures often calls for the use of quantitative information. As a result, it is advisable to combine these direct measures with firms' financial data. The resulting measures are often referred to as indexes.

\section{Indexes}

In order to avoid some of the disadvantages of direct and indirect measures of financial constraints, the combination of different types of information and different variables into indexes provides a useful tool in the analysis of firms' constraints. The main motivations for the use of indexes is that they allow a firm-specific treatment of financial constraints, as well as they can be used either as dependent or explanatory variables, due to their continuous nature. ${ }^{15}$

\subsection{With a qualitative dependent variable}

The use of indexes of financial constraints is rather recent. This approach was, to our knowledge, first implemented by Lamont et al. (2001). Using KZ's ordered logit regression of financial constraints scores on relevant financial variables (see Section 3.1), they propose a firm-specific and time-varying index of constraints (known in the literature as the KZ index). ${ }^{16}$

The idea is that, given a qualitative variable of financial constraints, one can estimate the impact of a number of different determinants of financial constraints. These determinants are usually proxies that are expected to influence firms ability to obtain external finance (see Appendix Table 1). Using the appropriate non-linear regression technique, one can estimate coefficients for each of the determinants of constraints. ${ }^{17}$ Having obtained these coefficients, it is then possible to construct an index that results from a linear combination of the determinants, weighted by the estimated coefficients (see Table 1).

\footnotetext{
${ }^{13}$ Note that this is a bank level survey that does not contain firm-specific information. Therefore, one can only observe the evolution of the credit policies, demand and supply of funds within banks' perspective.

${ }^{14}$ As an example, cooperation with the vast majority of banks with desired levels of regional and industry representativeness (branch representativeness) would be necessary.

${ }^{15}$ Note that the Class Ranking Index (Section 4.2.3) is an exception.

16 The index is given by $\mathrm{KZ}_{\mathrm{it}}=-1.002 * \mathrm{CF}_{\mathrm{it}}+3.139 * \mathrm{~B}_{\mathrm{it}}-39.368 * \mathrm{D}_{\mathrm{it}}-1.315 * \mathrm{C}_{\mathrm{it}}+0.283 * \mathrm{Q}_{\mathrm{it}}$, where CF is cash-flow over total assets, B is long-term debt over total assets, D is total dividends over total assets, C is liquid assets over total assets, and Q is Tobin's q.

17 The estimation of the coefficient is based on a latent variable specification (since the dependent variable is binarylordinal). See for example Greene and Hensher (2010) for details.
} 
Even though the outcome is a continuous, firm-specific and time-varying measure of constraints, there are a number of problems associated with this approach. First, it relies on the availability of a qualitative dependent variable. Therefore, it also carries along all the sampling and subjectivity issues raised in Section 3.

Second, the index is constructed using a specific sample of firms. Accordingly, it is not reasonable to expect that the corresponding coefficients will remain unchanged if one intends to apply it to a different sample - see Silva and Carreira (2010a) for a discussion of the Size-Age index (Hadlock and Pierce, 2010). Consequently, the index can not be universally used as a measure of financial constraints.

Third, unless the non-linear regression has a very good fit, the corresponding index will only provide a noisy signal of financial constraints. This bias will be particularly severe if there are a number of unobservable andlor omitted variables in the regression that strongly determine financial constraints.

\subsection{Without a qualitative dependent variable}

In order to avoid the problems associated with the availability of qualitative data and sample specificity, a number of researchers have constructed indexes that do not rely on this type of data. We summarize these indexes into the three following categories.

\subsubsection{Euler equation index}

Building on the Euler equation approach (Section 2.3), Whited and Wu (2006) construct an index of constraints that does not require qualitative information. Instead, they use a structural parameter of the Whited (1992) model - the shadow cost of equity finance - that is set to be a function of observable firm characteristics.

In practice, the strategy boils down to estimate the Euler equation model's resulting empirical equation. In this framework, the shadow cost of finance is set, outside of the model, to be a function of observable «financial health» variables. As a result, they obtain a vector of coefficients, that is then used to build the index (known in the literature as the WW index). ${ }^{18}$

Although the data requirements for the construction of this index are not particularly difficult to meet - essentially balance sheet data and financial markets information -, the major concern when using this approach is the fact that the index results from a highly parameterized structural model (as in Section 2.3). Additionally, due to the number of parameters involved in the underlying model, this approach is of far more complex implementation than any other measure discussed here. Finally, as in the preceding Section, we should note that the estimated coefficients (hence the index) are sample-specific, which precludes any straightforward generalization.

\subsubsection{MDA index}

An alternative strategy that neither requires a qualitative dependent variable nor a structural underlying model was implemented by Cleary (1999). Using multiple discriminant analysis (MDA), one can examine which variables are likely to influence the characterization of a firm as either financially constrained or non-financially constrained - in line with Altman (1968) for the case of bankruptcy.

\footnotetext{
18 The index is given by $\mathrm{WW}_{\mathrm{it}}=-0.091 * \mathrm{CF}_{\text {it }}+0.021 * \mathrm{~B}_{\text {it }}-0.062 * \mathrm{D}_{\mathrm{it}}-0.044 * \mathrm{~A}_{\mathrm{it}}+0.035 * \mathrm{Y}_{\mathrm{it}}+0.102 * \mathrm{Y}_{\text {it }}$, where CF is cash-flow over total assets, $B$ is long-term debt over total assets, $D$ is an indicator of whether or not a firm pays cash dividends, $A$ is the logarithm of total assets, $Y$ is sales growth and $I Y$ is the 3-digit industry sales growth.
} 
The procedure requires two steps. First, one should use a segmenting variable that enables the distinction of firms into two (or more) mutually exclusive groups. Then, use MDA to assess the ability of each independent variable (determinants of financial constraints) to distinguish a firm between groups. As a result, one can build the index using the coefficients estimated through MDA. Within the same rationale, one can use the segmenting variable to distinguish two (or more) groups of firms (e.g. financially constrained and non-financially constrained) and then estimate a probitlogit on the determinants of financial constraints. The resulting coefficients will then be used to build the index. ${ }^{19}$

The major drawback of this approach is the need to have a superior segmenting variable that correctly discriminates between financially constrained and unconstrained firms. Cleary (1999) assumes that dividend policy serves as such variable because firms that reduce dividends are likely to be constrained, whereas a firm will only increase dividends if it knows it can maintain them (financially unconstrained). ${ }^{20}$ However, if the segmenting variable does not consistently discriminate between constrained and unconstrained firms, the resulting index will biased. This problem is similar to the choice of a variable for an a-priory firm classification (see Section 2).

\subsubsection{Class Ranking Index}

An alternative to the traditional indexes, first introduced by Musso and Schiavo (2008), is to rank firms in a certain class (e.g. region or industry) that is believed to be reasonably homogeneous. These rankings are computed upon on a number of variables that are found to have a given relationship to financial constraints (proxies). ${ }^{21}$ Therefore, one can build a score of constraints based on the relative rankings of a given number of variables for a certain firm, within a certain class. The motivation to disaggregate firms into homogeneous classes is to account for specificities that may affect the relationship between the proxies and the genuine level of constraints - for example, in some industries there might be a relationship between age and financial constraints.

The procedure requires two steps. Firstly, identify a number of variables that can serve as proxies of financial constraints - see Section 5.3. For each of these variables, compute the relative position of each firm to the corresponding class mean. Secondly, collapse the rankings from all the proxies into a single score of financial constraints. As an example, if a firm is very old and large, and has a higher dividend payout ratio, then it is considered not to be constrained. If the converse is true, then such firm is assigned as constrained. Intermediate levels may also be built based on the ranking - quantiles of these variables. Examples of this approach can also be found in Bellone et al. (2010) and Silva (2011).

A first problem arises if we wish to use the score of constraints as a continuous variable. In fact, the score variable is ordinal. One cannot be sure that the difference between a firm scoring 1 and 2 is the same as the difference between levels 2 and 3 . As a result, the score must be taken as an ordinal variable, which has significant implications in the choice of the estimation procedure.

Secondly, if there are non-linearities in the relationship between the proxy and the effective level of constraints, the final score will misrepresent the level of constraints. As an example, while it is generally agreed that financial constraints are lower for larger and older firms, we point out that

\footnotetext{
${ }^{19}$ Note that multiple discriminant analysis is the predecessor of non-linear approaches such as the probit and logit. One can see the $Z$ score as a latent variable of financial constraints, as in Section 4.1.

20 This type of segmenting variable usually further requires information from financial markets, which may result in biased samples.

${ }^{21}$ Musso and Schiavo (2008) construct their index based on the following variables: size (total assets), profitability, liquidity (current asset over current liabilities), cash flow generating ability (the maximum amount of resources that a firm can devote to self-financing), solvency (own funds over total liabilities), trade credit over total assets, repaying ability (financial debt over cash flow).
} 
such relationship might rather be non-monotonic (U-shaped). If this is the case, then we will have firms assigned the maximum score, while in fact they face a lower level of constraints.

Finally, we should point that the disaggregation in relatively homogeneous classes of firms might entail considerable difficulties when comparing firms across classes. As an example, if the index is built on relative rankings for each industry, and if the less constrained firms in industry $A$ is more constrained than the most constrained firm in industry $B$, comparison of firms across the two groups will be misleading. 22

\section{Other approaches}

\subsection{Firm level cash-flow sensitivities}

A recent strand of literature, based on the CFS rationale, tries to overcome the problems associated with aggregation, as well as a priori classification schemes that CFS approaches usually face. This approach consists in introducing firm-level heterogeneity in the measure of financial constraints, without requiring the use of qualitative data or heavily parameterized underlying models. Within this framework, two different methodologies should be mentioned: i) Hovakimien and Hovakimien (2009), hereafter HH, and ii) D'Espallier, Vandemaele and Peeters (2008), hereafter EVP.

The measure introduced by $\mathrm{HH}$ compares the time average of investment weighted by cash-flow, against the simple average investment. Accordingly, investment in years when cash-flow is higher receives a higher weight, which means that if a firm invests more (less) in years with higher cash flow, the $\mathrm{HH}$ index will turn our positive (negative). The converse is also true. As a result, this measure is expected to capture the sensitivity of investment with respect to variations in cash-flows. The approach can also be extended to other types of CFS (see Section 2.1).

However simple, this methodology fails to control for investment opportunities and other variables affecting investment. As an example, the ICFS test relies on the assumption that, holding investment opportunities constant, investment responds positively to cash-flow if a firm is financially constrained (no sensitivity should be found for unconstrained firms). Additionally this measure does not explore marginal effects (see D'Espallier et al., 2009 for a critique).

A different perspective, introduced by EVP, is to estimate heterogeneous cash-flow slopes of a CFS regression. Using the same rationale of a CFS regression, one obtains a coefficient vector instead of a scalar. As result, we will have a cash-flow sensitivity for each firm. Accordingly, in contrast with the $\mathrm{HH}$ index, this methodology controls for a number of other relevant variables affecting the dependent variable (e.g. investment opportunities). However, the estimation of firm-level slopes requires refined estimation techniques that may introduce some complexity in the implementation. ${ }^{23}$

Nevertheless, both these methodologies share two major shortcomings. Even though they are firm-specific, the extent to which firms move from financially unconstrained to constrained states and vice-versa is not captured by these time averages. Additionally, they require that the underlying CFS methodology consistently identifies and measures constraints.

\footnotetext{
${ }^{22}$ Note that firms operating in some industries are, on average, more constrained than firms in other industries (Silva and Carreira, 2010b).

${ }^{23}$ EVP use a Generalized Maximum Entropy estimator after Golan et al. (2006), while D'Espallier and Guariglia (2009) use Bayesian econometrics (c.f. Lancaster, 2004; Koop, 2003).
} 


\subsection{Credit ratings}

Credit ratings are the evaluation given by certain agencies to firms. These ratings are the basis for establishing the cost of external funding of a given credit rated firm - either by private investors in capital markets or by financial institutions.

The main benefit from using credit ratings is related to the fact that they summarize a vast set of firms' characteristics, are firm-specific and vary over time, as well as they represent the opinion of the markets (e.g Bottazzi et al., 2008, for an application). Even though this measure partially captures the credibility of a given firm in the market for funds, it has three major pitfalls.

Firstly, it relies on the quality of the assessment of credit rating agencies. In other words, one must believe that these agencies correctly screen credible companies. ${ }^{24}$ Secondly, these ratings are based on the credibility of a given firm at a certain point in time (mostly relying on past economic and financial information, as well as default events). This means that they may fail to capture the true quality of investment projects to be overtaken in the near future. Thirdly, there are sample representativeness problems. In general, firms that ask to be rated are usually large, mature and traded - we would expect them to be unconstrained, or at least, less constrained than the average firm (see Carreira and Silva, 2010). This problem can be partially addressed if, in the analysis of a larger sample that covers non-rated firms, one classifies firms as constrained or not, depending on being rated or not, rather than on the rating itself. Once again, we might incur in significant biases if there exist unconstrained firms that avoid being rated simply because they do not want to depend on such ratings for obtaining external finance. Furthermore, some firms may, at some point, become «too big» or «too important» to be downgraded, even though an objective analysis would suggest so.

We note that the type of rating abovementioned might be different from a closer credit risk assessment that, for example, banks usually do. Such analysis might prove to be more accurate than credit ratings (strictu-sensu). However, aside credibility issues, such information is rarely available to the researcher.

\subsection{Proxies}

The use of proxies is the simplest and most practical way to measure constraints. By definition, if a given variable is highly correlated with financial constraints, it may prove to be a good proxy. If a proxy is available, then it can easily be used as either a dependent or explanatory variable that is firm-specific and time-varying.

The large majority (if not all) of the empirical literature on financial constraints relies on a different variety of proxies either as explanatory or segmenting variables. Examples of commonly used proxies are the following: Cash-flow, Cash stocks, Size, Age, Export, R\&D intensity, Leverage, Dividend payout ratio, Group membership and Ownership.

Even though there might be different variables that correlate with financial constraints, a good proxy for financial constraints is rather hard to find (Cleary et al., 2007). Additionally, the use of proxies relies on previous relationships between financial constraints and the selected variable. Finally, if these relationships are non-monotonic, then the corresponding variable will only work as a good proxy for a subset of its space (see Section 2.2.4).

\footnotetext{
${ }^{24}$ Note that the rating itself results from a multivariate score summarizing firms' characteristics or a collection of information from financial statements and reports.
} 
The analysis of firms' access to finance has been sensitive to methodological challenges. This paper overviews the existing frameworks used to identify and measure financial constraints.

It is clear by now that the researcher can choose from wide range of different measures, with perhaps complementary advantages and disadvantages. Therefore it is hard to clearly point a superior approach. In fact, we would risk saying that there is no perfect measure of financial constraints. This scenario has serious implications on economic research and certainly on policymaking.

While future research should definitely make an effort to develop better methodologies to assess firms' financial constraints, empirical work on this field should be cautious when providing conclusions and suggesting policy actions.

Finally, policymakers should not take single studies as the sole basis for policy action and design of policy instruments, be it tax credits, subsidies, special lines of credit, credit guarantee schemes or equity instruments. In particular, if such policies require redirecting public funds from other public purposes, market distortions might be the result in the event that funds are not correctly allocated to constrained firms. 
Acharya, V.; Almeida, H.; Campello, M. (2007) Is cash negative debt? A hedging perspective on corporate financial policies, Journal of Financial Intermediation, 16(4), 515-554.

Almeida, H.; Campello, M.; Weisbach, M.S. (2004) The cash flow sensitivity of cash, Journal of Finance, 59(4), 1777-1804.

Almeida, H.; Campello, M.; Weisbach, M. (2011) Corporate financial and investment policies when future financing is not frictionless, Journal of Corporate Finance, 17(3), 675-693

Alti, A. (2003) How sensitive is investment to cash flow when financing is frictionless?, Journal of Finance, 58(2), 707-722.

Altman, Edward I. (1968) Financial ratios, discriminant analysis and the prediction of corporate Bankruptcy, Journal of Finance, 23(4), 589-609.

Angelini, P.; Generale, A. (2005) Firm size distribution: do financial constraints explain it all? Evidence from survey data, Temi di Discussione no. 549, Banca d'Italia.

Audretsch, D.B.; Elston, J.A. (2002) Does firm size matter? Evidence on the impact of liquidity constraints on firm investment behavior in Germany, International Journal of Industrial Organization, 20(1), 1-17.

Baum, C.; Schäfer, D.; Talavera, O. (2011) The impact of the financial system's structure on firms' financial constraints, Journal of International Money and Finance, 30(4), 678-691.

Beck, T.; Demirgüç-Kunt, A.; Maksimovic, V. (2008) Financing patterns around the world: Are small firms different?, Journal of Financial Economics, 89(3), 467-487.

Bellone, F.; Musso, P.; Nesta, L.; Schiavo, S. (2010) Financial constraints and firm export behavior, World Economy, 33(3), 347-373.

Blundell, R.; Bond, S.; Devereux, M.; Schiantarelli, F. (1992) Investment and Tobin's Q: Evidence from company panel data, Journal of Econometrics, 51(1-2), 233-257.

Bond, S.; Meghir, C. (1994) Dynamic Investment Models and the Firm's Financial Policy, Review of Economic Studies, 61(2), 197-222.

Bond, S.; Elston, J.A.; Mairesse, J.; Mulkay, B. (2003) Financial factors and investment in Belgium, France, Germany, and the United Kingdom: A comparison using company panel data, Review of Economics and Statistics, 85(1), 153-165.

Bottazzi, G.; Secchi, A.; Tamagni, F. (2008) Productivity, profitability and financial performance, Industrial and Corporate Change, 17(4), 711-751.

Brainard,W.; Tobin, J. (1968) Pitfalls in financial model building, American Economic Review, 58, 99-122.

Carpenter, R.E.; Petersen, B.C. (2002) Is the growth of small firms constrained by internal finance?, Review of Economics and Statistics, 84(2), 298-309.

Carreira, C.; Silva, F. (2010) No Deep Pockets: Some stylized results on firms' financial constraints, Journal of Economic Surveys, 24(4), 731-753.

Chapman, D.R.; Junor, C.W.; Stegman, T.R. (1996) Cash flow constraints and firms' investment behavior, Applied Economics, 28(8), 1037-1047.

Chirinko, R. S. (1993) Business Fixed Investment spending: Modeling strategies, empirical results, and policy implications, Journal of Economic Literature, 31(4), 1875-1911.

Claessens, S.; Tzioumis, K. (2006) Measuring firms' access to finance, World Bank and Brooking conference paper, Mimeo. 
Cleary, S. (1999) The relationship between firm investment and financial status, Journal of Finance, 54(2), 673-692.

Cleary, S.; Povel, P.E.; Raith, M. (2007) The U-shaped investment curve: Theory and evidence, Journal of Financial and Quantitative Analysis, 42(1), 1-39.

Coad, A. (2007) Testing the principle of 'growth of the fitter': The relationship between profits and firm growth, Structural Change and Economic Dynamics, 18(3), 370-386.

Coad, A. (2010) Neoclassical vs. evolutionary theories of financial constraints: Critique and prospectus, Structural Change and Economic Dynamics, 21(3), 206-218.

Czarnitzki, D.; Hottenrott, H. (2011) Financial constraints: Routine versus cutting edge R\&D investment, Journal of Economics and Management Strategy, 20(1), 121-157.

Del Giovane, P.; Eramo, G.; Nobili, A. (2011) Disentangling demand and supply in credit developments: A survey-based analysis for Italy, Journal of Banking and Finance, 35(10), 2719-2732.

D'Espallier, B.; Guariglia, A. (2009) Does the investment opportunities bias affect the investment-cash flow sensitivities of unlisted SMEs?, University of Nottingham, CFCM Discussion Paper 09/12.

D’Espallier, B.; Vandemaele, S.; Peeters, L. (2008) Investment-cash flow sensitivities or cash-cash flow sensitivities? An evaluative framework for measures of financial constraints, Journal of Business Finance and Accounting, 35(7-8), 943-968.

D’Espallier, B.; Vandemaele, S.; Peeters, L. (2009) Corporate investment and financing constraints: Analyzing firm-varying investment-cash flow sensitivities, Review of Business and Economics, 54(4), 461-488.

Dosi, G., (2007) Statistical Regularities in the Evolution of Industries: A Guide Through Some Evidence and Challenges for the Theory. In Malerba, F., Brusoni, S. (eds.), Perspectives on Innovation, Cambridge, UK, Cambridge University Press.

Faggiolo, G.; Luzzi, A. (2006) Do liquidity constraints matter in explaining firm size and growth? Some evidence from the Italian manufacturing industry, Industrial and Corporate Change, 15(1), 1-39.

Fama, E. F. (1970) Efficient capital markets: A review of theory and empirical work, Journal of Finance, 25(2), 383-417.

Fazzari, S.M.; Hubbard, R.G.; Petersen, B.C (2000) Investment-cash flow sensitivities are useful: A comment on Kaplan and Zingales, Quarterly Journal of Economics, 115(2), 695-705.

Fazzari, S.M.; Hubbard, R.G.; Petersen, B.C. (1988) Financing constraints and corporate investment, Brookings Papers on Economic Activity, 0(1), 141-195.

Geroski, P. A.; Jacquemin, A. (1988) The persistence of profits: A European comparison, Economic Journal, 98(391), 357-389.

Golan, A.; Judge, G. G.; Miller, D. (1996) Maximum Entropy Econometrics: Robust Estimation with Limited Data, Indianapolis, John Wiley \& Sons.

Gomes, J.F. (2001) Financing investment, American Economic Review, 91(5), 1263-85.

Greene, W.; Hensher, D. (2010) Modeling Ordered Choices: A Primer, Cambridge, UK: Cambridge University Press.

Guariglia, A. (2008) Internal financial constraints, external financial constraints, and investment choice: Evidence from a panel of UK firms, Journal of Banking and Finance, 32(9), 1795-1809.

Guiso, L. (1998) High-Tech firms and credit rationing, Journal of Economic Behaviour and Organization, 35(1), 39-59. 
Hadlock, C. (1998) Ownership, liquidity, and investment, RAND Journal of Economics, 29(3), 487-508

Hadlock, C. J.; Pierce, J. R. (2010) New evidence on measuring financial constraints: Moving beyond the KZ index, Review of Financial Studies, 23(5), 1909-1940.

Han, S.; Qiu, J. (2007) Corporate precautionary cash holdings, Journal of Corporate Finance, 13(1), 43-57.

Hayashi, F. (1982) Tobin's marginal Q and average Q: A neoclassical interpretation, Econometrica, 50(1), 213-24.

Hovakimien A.; Hovakimien, G. (2009) Cash flow sensitivity of investment, European Financial Management, 15(1), 47-65.

Hubbard, R. G. (1998) Capital-market imperfections and investment, Journal of Economic Literature, 36(1), 193-225.

Kadapakkam, P.R.; Kumar, P.C.; Riddick, L.A. (1998) The Impact of cash flows and firm size on investment: The international evidence, Journal of Banking and Finance, 22(3), 293-320.

Kaplan, S.N.; Zingales, L. (1997) Do investment-cash flow sensitivities provide useful measures of financing constraints?, Quarterly Journal of Economics, 112(1), 169-215.

Kaplan, S.N.; Zingales, L. (2000) Investment-cash flow sensitivities are not valid measures of financing constraints, Quarterly Journal of Economics, 115(2), 707-712.

Koop, G. (2003) Bayesian Econometrics, New Jersey, Wiley-Interscience.

Lamont, O.; Polk, C.; Saa-Requejo, J. (2001) Financial constraints and stock returns, Review of Financial Studies, 14(2), 529-554.

Lancaster, T. (2004) An Introduction to Modern Bayesian Econometrics, New Jersey, Blackwell.

Lin, Y. (2007) The cash flow sensitivity of cash: evidence from Taiwan, Applied Financial Economics, 17(12), 1013-1024.

Love, I. (2003) Financial development and financing constraints: International evidence from the structural investment model, Review of Financial Studies, 16(3), 765-791.

Lyandres, E. (2007) Costly External Financing, Investment Timing, and Investment-Cash Flow Sensitivity, Journal of Corporate Finance, 13(5), 959-980.

Modigliani, F.; Miller, M. (1958) The cost of capital, corporation finance and the theory of investment, American Economic Review, 48(3), 261-297.

Musso, P.; Schiavo, S. (2008) The impact of financial constraints on firm survival and growth, Journal of Evolutionary Economics, 18(2), 135-149.

Nelson, R. R. (1995) Recent evolutionary theorizing about economic change, Journal of Economic Literature, 33(1), 48-90.

Nelson, R. R.; Winter, S. G. (1982) An Evolutionary Theory of Economic Change, Cambridge, MA: Harvard University Press.

OECD (2012) Financing SMEs and Entrepreneurs 2012: An OECD Scoreboard, OECD Publishing

Oliveira, B.; Fortunato, A. (2006) Firm growth and liquidity constraints: A dynamic analysis, Small Business Economics, 27(2), 139-156.

Pál, R.; Ferrando, A. (2009) Financing constraints and firms' cash policy in the Euro area, European Journal of Finance, 16(2), 153-171.

Povel, P.; Raith, M. (2002) Optimal investment under financial constraints: The roles of internal funds and asymmetric information, AFA 2002 Atlanta Meetings. 
Russo, P.; Rossi, P. (2001) Credit constraints in Italian industrial districts, Applied Economics, 33(11), 1469-1477.

Sarno, D. (2008) Financial and legal constraints to firm growth: The case of Italy, Journal of Applied Economic Sciences, 3(3), 293-305.

Savignac, F. (2009) Impact of financial constraints on innovation: What can be learned from a direct measure?, Economics of Innovation and New Technology, 17(6), 553-569.

Scellato, G. (2007) Patents, firm size and financial constraints: An empirical analysis for a panel of Italian manufacturing firms, Cambridge Journal of Economics, 31(1), 55-76.

Schumpeter, Joseph A. (1939; 1968) Business Cycles: A Theoretical, Historical, and Statistical Analysis of the Capitalist Process, Cambridge, MA, Harvard University Press.

Serrasqueiro, Z.; Nunes, P.; Leitão, J.; Armada, M. (2010) Are there non-linearities between SME growth and its determinants? A quantile approach, Industrial and Corporate Change, 19(4), 1071-1108.

Silva, A. (2011) Financial constraints and exports: evidence from Portuguese manufacturing firms, FEP Working Papers No. 402.

Silva, F.; Carreira, C. (2010a) Measuring firms' financial constraints: Evidence for Portugal through different approaches, GEMF Working Paper No. 15/2010.

Silva, F.; Carreira, C. (2010b) Financial constraints: Are there differences between manufacturing and services?, GEMF Working Paper No. 16/2010.

Simon, H. (1991) Bounded rationality and organizational learning, Organization Science, 2(1), 125-134.

Tobin, J. (1969) A general equilibrium approach to monetary theory, Journal of Money, Credit, and Banking, 1, 15-29.

Whited, T.; Wu, G. (2006) Financial constraints risk, Review of Financial Studies, 19(2), 33-72.

Whited, T. M. (1992) Debt, liquidity constraints, and corporate investment: Evidence from panel data, Journal of Finance, 47(4), 1425-1460. 


\section{2 43

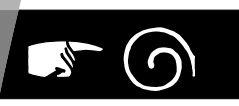

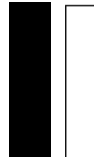
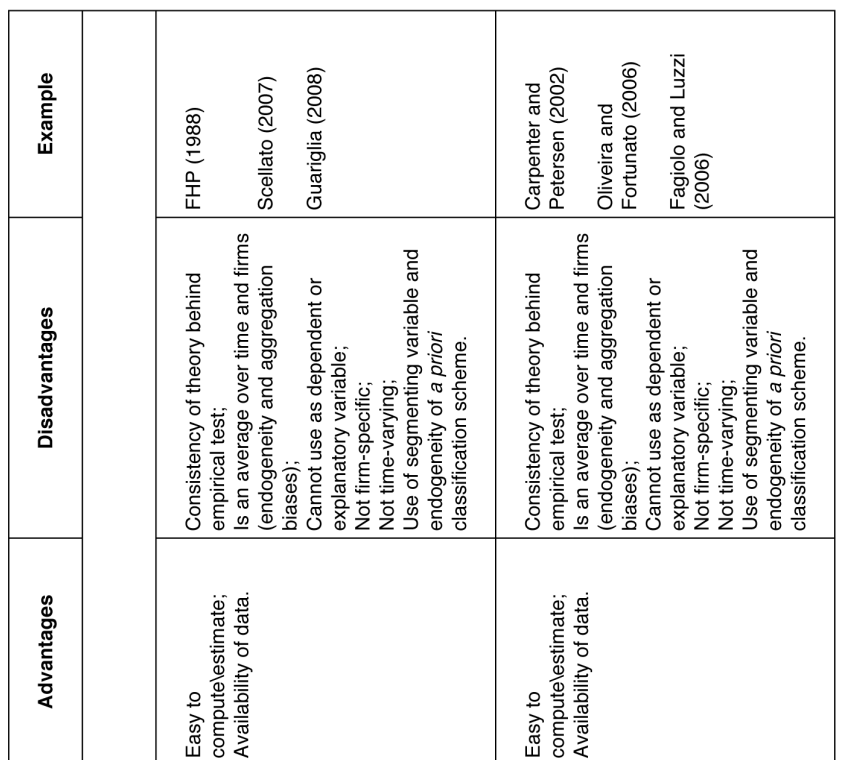

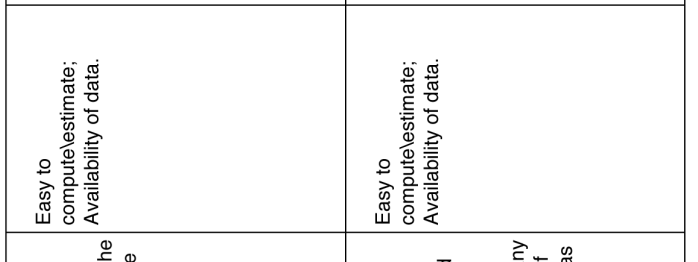

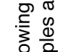

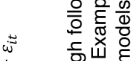

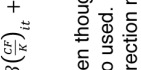

2
+

궁

II

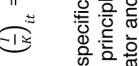

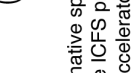

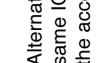

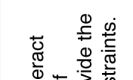

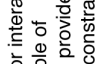

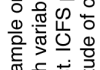

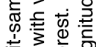

के

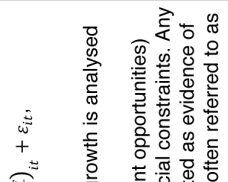

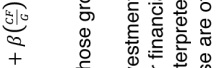

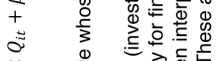

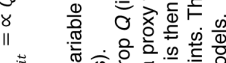

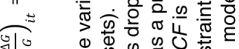

包 $\begin{array}{lll}0 \\ 0\end{array}$

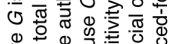

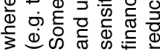

की

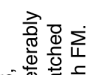

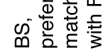

帝

害琼

政

을

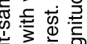

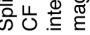

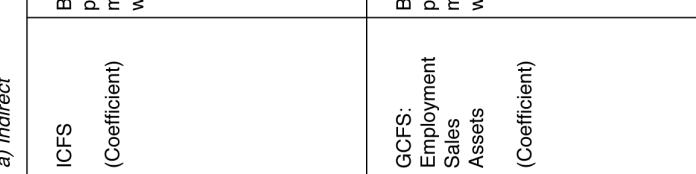


Measuring Firms' Financial Constraints:

\begin{tabular}{|c|c|c|c|}
\hline 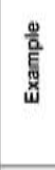 & 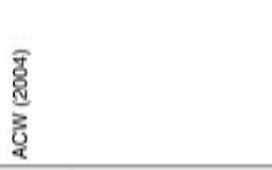 & 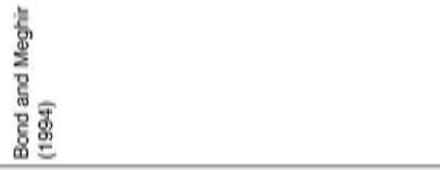 & $\begin{array}{l}5 \\
\frac{d}{8} \\
\frac{\pi}{8} \\
\end{array}$ \\
\hline 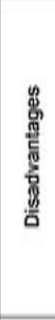 & 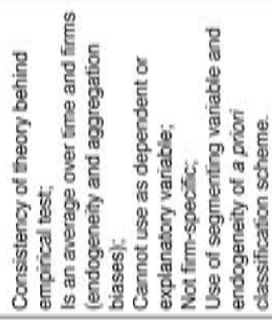 & 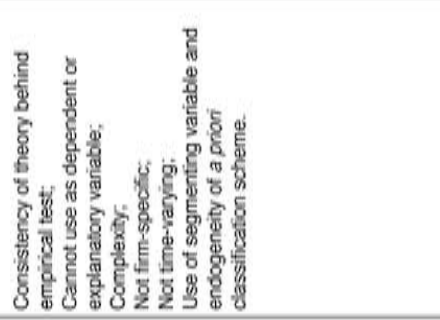 & 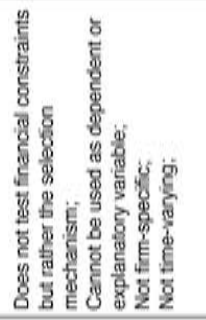 \\
\hline 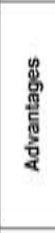 & 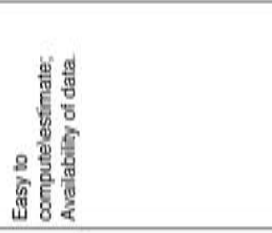 & 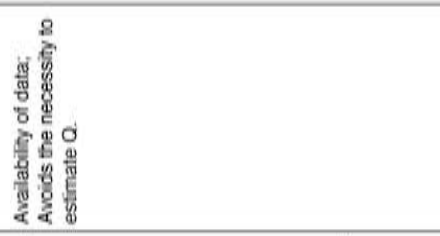 & 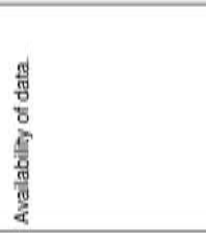 \\
\hline 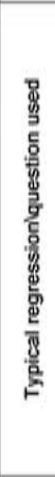 & 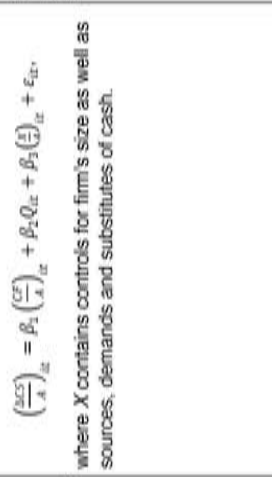 & 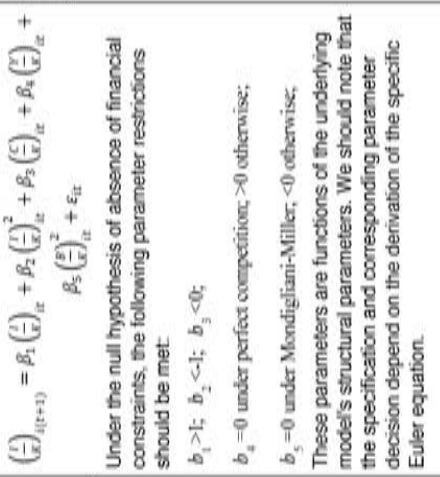 & 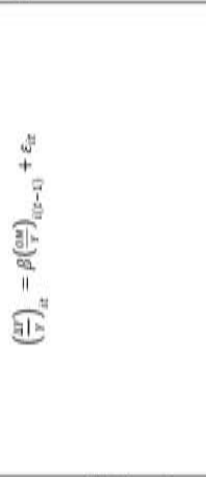 \\
\hline 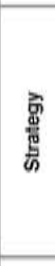 & 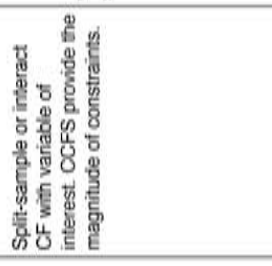 & 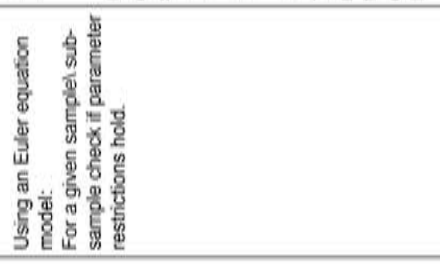 & 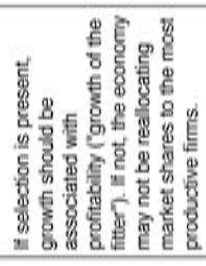 \\
\hline & 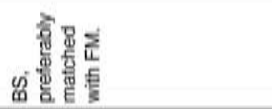 & 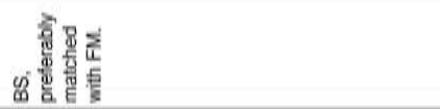 & 㽞 \\
\hline & 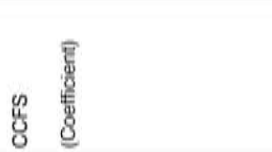 & 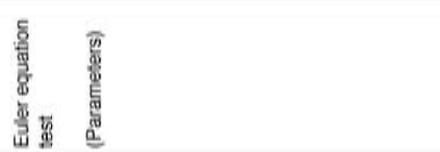 & 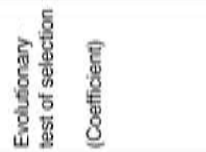 \\
\hline
\end{tabular}

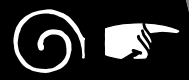




\section{4 45

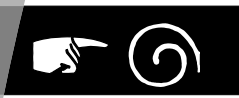

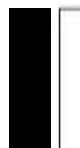
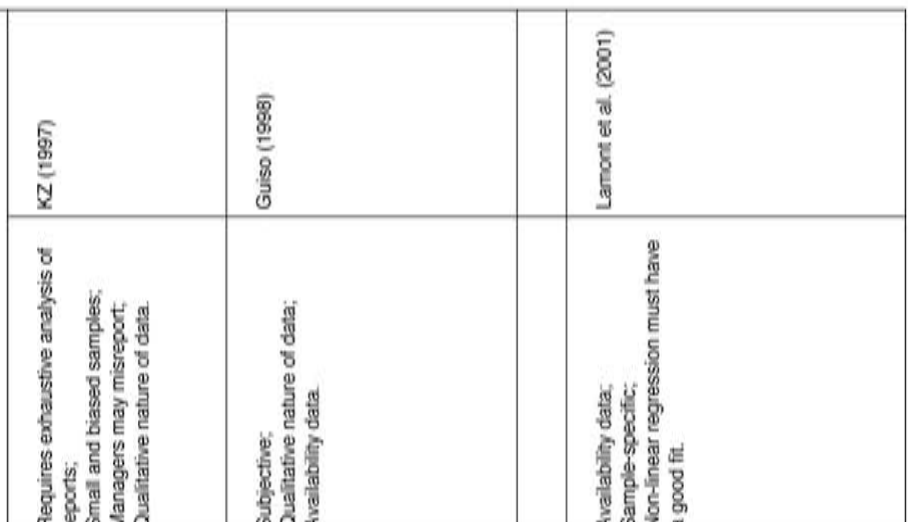

min

\begin{tabular}{|c|c|c|}
\hline 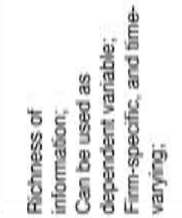 & 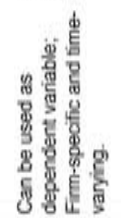 & 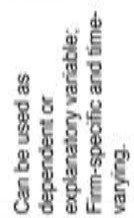 \\
\hline
\end{tabular}
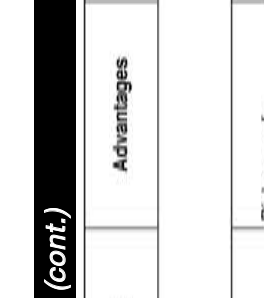

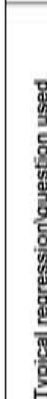

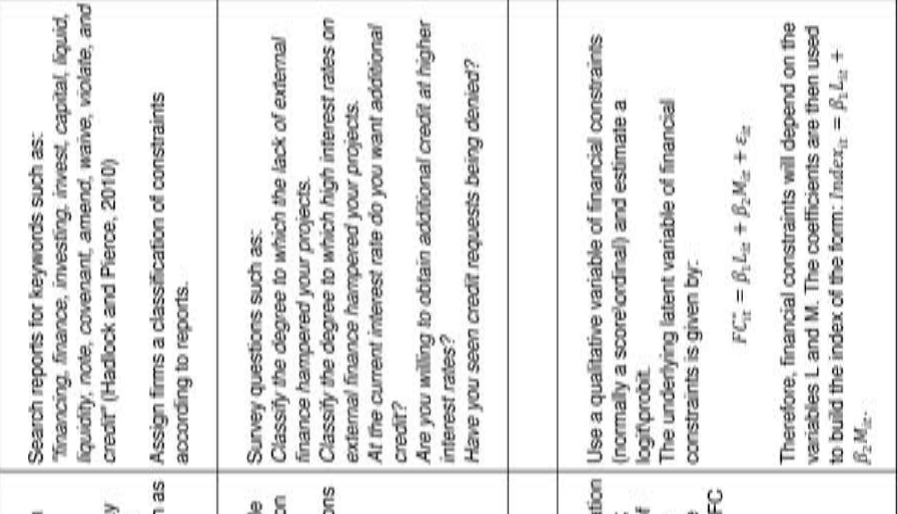

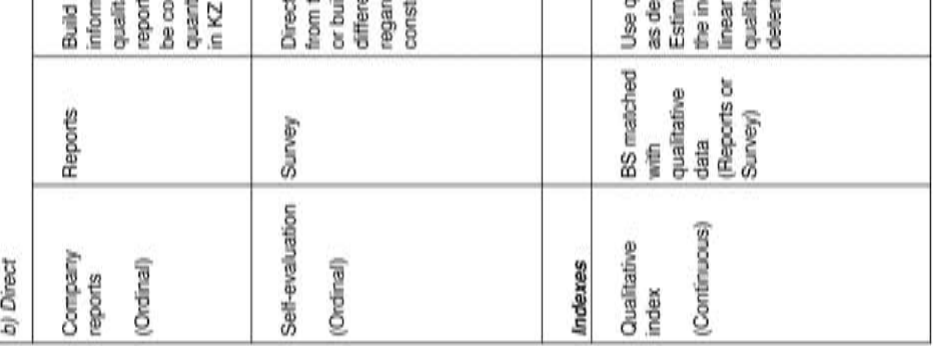


Measuring Firms' Financial Constraints:
Filipe Silva

Carlos Carreira

\begin{tabular}{|c|c|c|c|c|}
\hline $\begin{array}{l}\text { 产 } \\
\text { E } \\
\text { 查 }\end{array}$ & \multicolumn{2}{|l|}{ 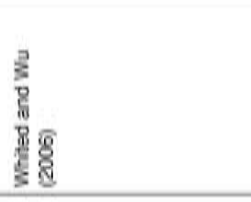 } & 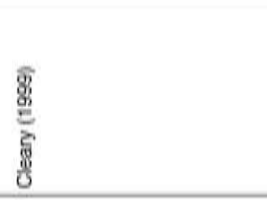 & 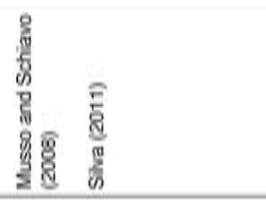 \\
\hline 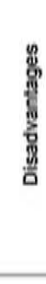 & \multicolumn{2}{|l|}{ 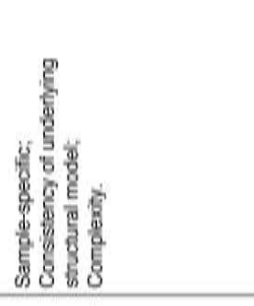 } & 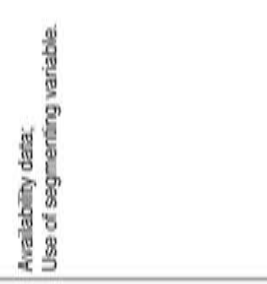 & 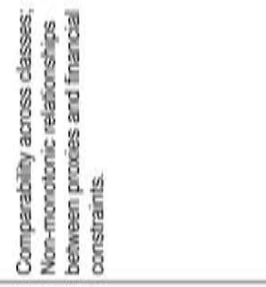 \\
\hline 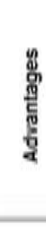 & \multicolumn{2}{|c|}{ 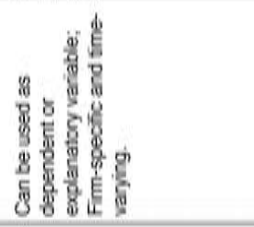 } & 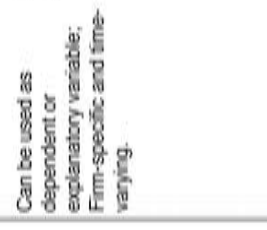 & 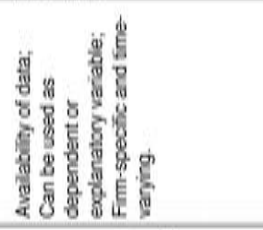 \\
\hline 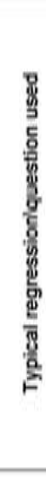 & 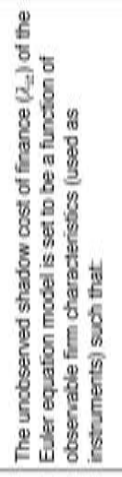 & 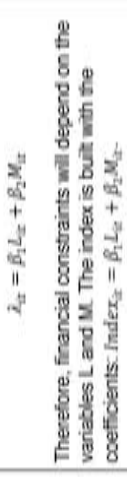 & 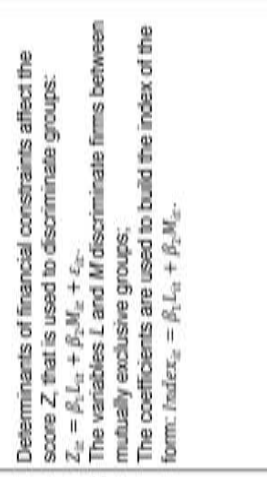 & 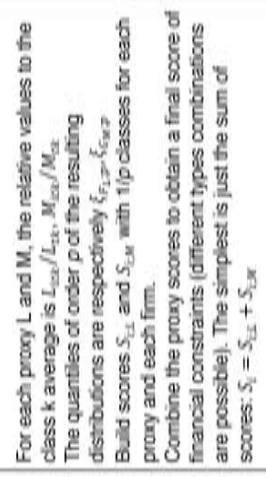 \\
\hline 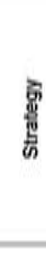 & 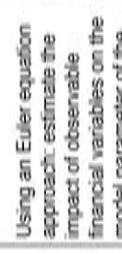 & 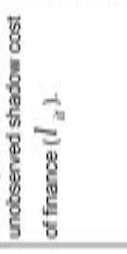 & 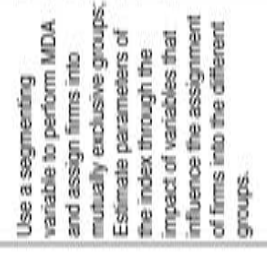 & 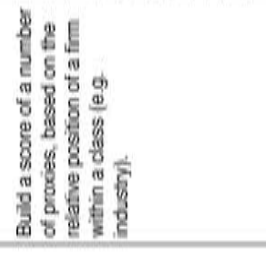 \\
\hline 픔 & 竞 & & 妾 & 留 \\
\hline 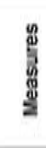 & 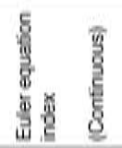 & & 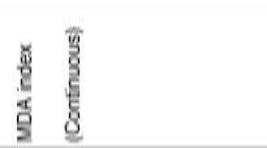 & 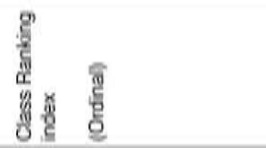 \\
\hline
\end{tabular}

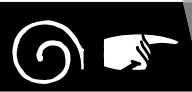




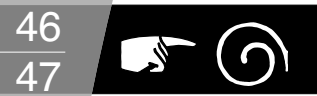

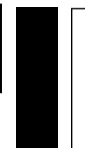

\begin{tabular}{|c|c|c|c|}
\hline $\begin{array}{l}\text { 递 } \\
\text { 焉 }\end{array}$ & 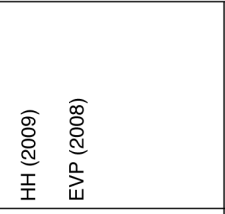 & 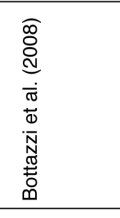 & \\
\hline 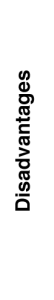 & 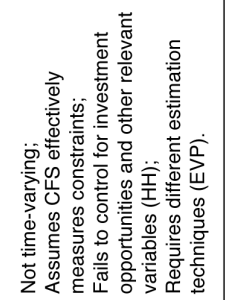 & 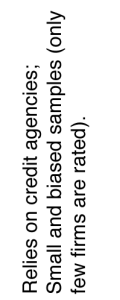 & 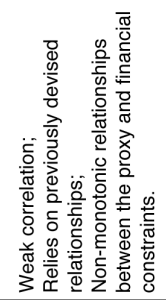 \\
\hline & $\ddot{\bar{I}} \quad \ddot{\theta}$ & . & \& \\
\hline
\end{tabular}

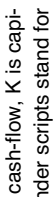

勿

굴

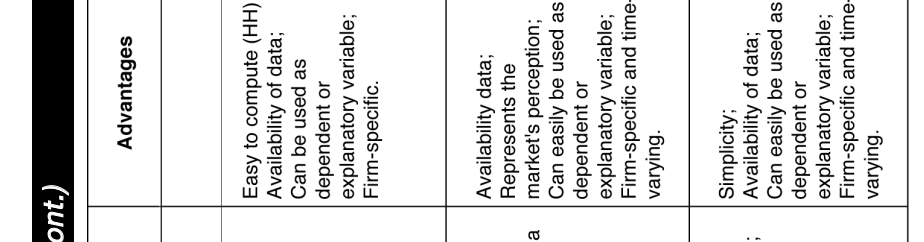

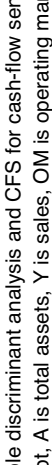

\begin{tabular}{|c|c|c|c|c|c|}
\hline 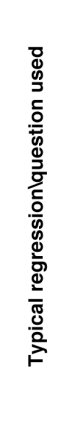 & 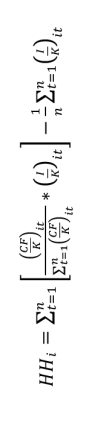 & 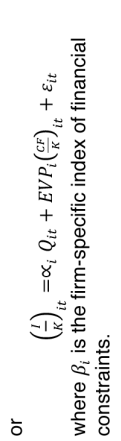 & 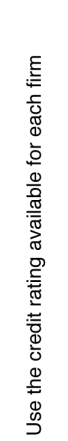 & 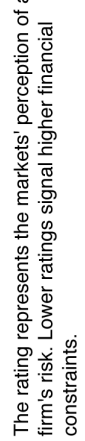 & 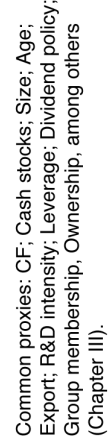 \\
\hline
\end{tabular}

\begin{tabular}{|c|c|c|c|c|}
\hline 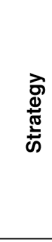 & & 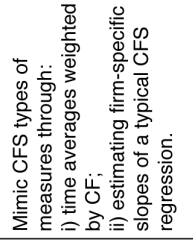 & 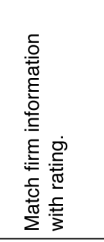 & 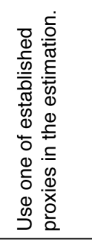 \\
\hline 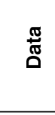 & & $\stackrel{\infty}{\infty}$ & 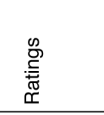 & 邑 \\
\hline 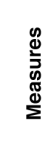 & $\begin{array}{l}\bar{y} \\
\bar{y} \\
0 \\
0\end{array}$ & & 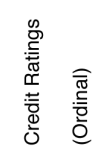 & 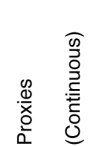 \\
\hline
\end{tabular}

产

흐

至

들

竞

里

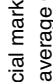

密

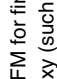

定

产

这

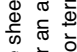

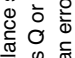

需

क응

흥

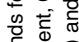

